\title{
REBALANCING HUMAN RIGHTS AT THE TIME OF COVID-19 PANDEMIC
}

\begin{abstract}
The year of 2020 will certainly be in all future books on the history of epidemiology and the Covid-19 pandemic will be discussed in them as perhaps the most significant public health challenge since the Spanish flu. But I also hope that it will feature as a new chapter in the books on health and human rights. The suffering of millions of people around the world, the deaths and medical challenges have already presented many lessons to learn from.

One of the lessons should be to recognize the right to health as a full-fledged human and constitutional right that deserves a much closer attention whenever annual budgets are drafted and it should be considered as a fundamental human right without which no other rights can be exercised in epidemiological crises and even after that.
\end{abstract}

Key words: Covid-19 pandemic, human rights, right to health, bioethics, rebalancing human rights.

\section{INTRODUCTION}

It is not the first time that humankind has experienced an epidemic. The Black Death resulted in about 100 million deaths between the $14^{\text {th }}$ and $17^{\text {th }}$ centuries in Asia and Europe. In 1918-1919 the Spanish flu pandemic caused approximately 50-100 million deaths worldwide.

Starting with Italy at the end of February 2020, the populations of European countries became part of a worldwide human experiment during the Spring months, participating in the first, global, top-down attempt at confinement in modern history - not quite voluntarily, but still subjecting ourselves to restrictive measures affecting all spheres of our lives. This unpredictable grand lockdown was not based on a known and effective scenario but was rushed on us overnight and framed almost everywhere by governmental and professional improvisations. We had dreamed of a

Full professor at the Central European University, and Director of the Center for Ethics and Law in Biomedicine (CELAB); e-mail: sandorj@ceu.edu 
twenty-first century, technologically advanced health care, but suddenly found ourselves in the early twentieth century. In the lack of previous workable models, people desperately searched for various sources that seemed to make sense, either in scientific literature or among opinions denying science.

It will take much more time and require more data accumulated to draw definitive lessons from health policy and epidemiology. In this article my aim is to examine the impact of this pandemic on human rights, especially on the right to health. While my research and analysis are based primarily on the Hungarian case during the two waves of the pandemic, my human rights assessment takes, of course, also the global impact of the pandemic into consideration. My claim is that the global pandemic of Covid-19 affects all human rights: the right to life, freedom of expression, the right to privacy, the right not to be discriminated against, etc. In this paper I will focus mainly on the impact of the pandemic on the rights within the health care sector from the perspective of feminist ethics. I will elaborate a more sensitive bioethical approach that is based on the principle of care as opposed to utilitarian considerations.

\section{Pandemic as a Challenge to Human Rights}

The Covid-19 pandemic has challenged and tested all health care systems in the world throughout the whole year of 2020. At the time of my writing this article we have already been in the ninth month into this unique global historical event and it is now time to draw some conclusions.

The various countries in the world reacted differently to the coronavirus epidemic. As the city of Wuhan in China had to cope with the consequences of the epidemic first, it provided a model for dealing with the pandemic for the rest of the world. As a result, drastic measures, including lockdowns, were implemented throughout the world, even in many liberal European states. However, these could only mask the bitter reality that most countries were simply unprepared for handling a pandemic. In the first wave of the pandemic in the spring, there were not enough critical care beds available, especially in Italy and Spain. As during the first wave the pandemic affected mainly the elderly, those countries where a significant portion of the society came from the elderly suffered tremendous losses within a short period of time.

Although most of the European countries implemented strict policies to flatten the epidemic curve in the spring, the United Kingdom did not 
follow this trend. ${ }^{1}$ Sweden did not implement such restrictions either. It became clear that European countries were unable to cooperate and develop policy coordination between each other beyond allocating financial aid. One can see a sharp contrast between the words of Charles Michel, President of the European Council, who declared that "only a shared spirit of global solidarity and responsibility will defeat the Covid-19 crisis," ${ }^{2}$ and the actual help that Member States provided to each other. Although the Member States of the European Union would have many opportunities to act together, they responded to the crisis mainly by introducing lockdowns and not by helping each other out. Italy was the first European country that was hit by the pandemic. By March 2020 the situation in Lombardia had become tragic: intensive care units were filled with seriously ill patients and the death rate increased sharply, especially among the elderly. ${ }^{3}$ On February 26, 2020 an urgent request was sent from Rome to the European Commission in Brussels. The message included the specifications of Italy's needs, and was uploaded into the EU's Common Emergency Communication and Information System (CECIS). Very sadly, no member state responded to Italy's request and to the Commission's call for help. ${ }^{4}$ The serious weaknesses in European integration were further demonstrated by the inability of the European Union to respond to the authoritarian tendencies that some Member States showed in their pandemic legislation. ${ }^{5}$

The World Health Organization did not have the same power and reputation as before. In the lack of a coherent view on the pandemic, in

1 Helm, T., Harrison, E., Mackie, R., 2020, How Did Britain Get Its Coronavirus Response So Wrong? The Guardian, April 19, (www.theguardian.com/world/2020/apr/18/ how-did-britain-get-its-response-to-coronavirus-so-wrong, 10. 11. 2020).

2 Opening remarks by President Charles Michel at the Global Response Pledging Event against Coronavirus (https://www.consilium.europa.eu/hu/press/press-releases/2020/05/04/speech-by-president-charles-michel-at-the-coronavirus-global-response-international-pledging-event/).

3 Nicoli F., Gasparetto, A., 2020, Italy in a Time of Emergency and Scarce Resources: The Need for Embedding Ethical Reflection in Social and Clinical Settings, Journal of Clinical Ethics, Vol. 31, No. 1 (Spring), pp. 92-94.

4 Boffey, D. et al., 2020, Revealed: Italy's Call for Urgent Help Was Ignored When Coronavrius Swept Through Europe, The Guardian, July 15, (www.theguardian.com/ world/2020/jul/15/revealed-the-inside-story-of-europes-divided-coronavirus-response, 10. 11. 2020).

5 Flynn, T. et al., Global, Regional and Comparative Perspectives, in: Ferstman, C. and Fagan, A. (eds.), 2020, Covid-19, Law and Human Rights: Essex Dialogues, A Project of the School of Law and Human Rights Centre, University of Essex, July 1, Colchester, University of Essex, pp. 29-30. Medicina Intensiva, 2020, Vol. 44, No. 6, (AugustSeptember), pp. 371-388.

Published online 2020 July 7. doi: 10.1016/j.medine.2020.04.003. 
many countries ethical guidelines were adopted. For instance, the Spanish Society of Intensive and Critical Medicine and Coronary Units issued recommendations. ${ }^{6}$ In Italy similar recommendations were adopted. ${ }^{7}$

In the fear of the pandemic human rights may seem as less important or something that we must restrict for the sake of safety. In fact, I would like to argue, human rights and safety measures are not based on mutually exclusive values. On the contrary, there are very important reasons to argue that the reinforcement of human rights is an essential element of personal safety. One compelling reason for that is that pandemic seems to be a long-lasting phenomenon now and governments, while taking necessary measures, may also use the pandemic as a justification for restricting human rights. It is extremely difficult to carefully separate the necessity created by the pandemic and the measures that are too broad and do serve some other political reasons. Secondly, it seems that the previous assessment of the right to health needs to be reexamined again. Right to health plays now an essential role in the enjoyment of other rights, as well.

Most importantly, I will argue, that this pandemic has transformed our notion of public health and the concept of right to health. We switched from the "Me Health to We Health", from the autonomy-based health care to restrictive measures and limited health care for the non-covid patients. Moreover, it is the first time that even healthy people are supposed to adopt their daily activities in order to flatten the curve and to diminish the burden of the health care system.

\subsection{GLOBAL ASPECTS OF HEALTH CARE}

\subsubsection{From Me-Health to We-Health?}

One of the most significant legal developments in the field of medical law was the recognition of the patients' rights, including the right to informed consent. Recognition of this autonomy played a crucial role in many fields of health care and this was the main pillar for a better, non-hierarchical doctor-patient relationship. Epidemic and pandemic do not deny the patient's autonomy, nevertheless for the interest of public safety

6 Ballesteros Sanz, M. Á. et al., 2020, Recommendations of the Working Groups from the Spanish Society of Intensive and Critical Care Medicine and Coronary Units (SEMICYUC) for the Management of Adult Critically Ill Patients in the Coronavirus Disease (Covid-19), Medicina Intensiva, Vol. 44, No. 6 (August-September), pp. 371-388.

7 Vergano, M. et al., 2020, Clinical Ethics Recommendations for the Allocation of Intensive Care Treatments, in Exceptional, Resource-Limited Circumstances, Version No. 1 (Rome: SIAARTI, March 16, 2020), (www.siaarti.it/SiteAssets/News/COVID19 - documenti SIAARTI/SIAARTI - Covid-19 - Clinical Ethics Reccomendations.pdf). 
it legitimizes some restrictions. Before the Covid-19 pandemic, whenever the health care system faced infectious diseases, the measures were applicable to the people who were infected. What is unusual in case of the Covid-19 pandemic is that basically the whole humankind has been and will remain subjected to some compulsory measure, irrespective of whether a concrete individual is infected or not. The fight is against an invisible virus, and most of the patients do not show any visible symptoms. Under the circumstances of this uncertainty the whole society has to accommodate to extraordinary restrictions on their daily life, work, studies, health care, vacation, art, and social elations.

Donna Dickenson ${ }^{8}$ wrote about "Me Medicine" vs. "We Medicine" in the context of genetics, but her metaphor is also valid in case of pandemic when individual health also depends on collective efforts.

It can be seen from the Covid-19 cases that this virus does not discriminate between the famous and the unknown, the poor and the rich. No matter how expensive health services someone is able to pay for; affluence may not stop him or her from contracting the virus.

No fame, no wealth, not even nobility or high political function could have saved Tom Hanks, Boris Johnson, Harvey Weinstein, Sophie Gregoire Trudeau, Placido Domingo, or Prince Charles from contracting the virus. Even some politicians have died as a result of catching the virus, including the Mayor of Vicenza. And many doctors, health care workers, as well - among them the whistleblower, Li Wenliang, who wanted to warn the world about the spread of the virus.

The current Covid-19 crisis has been a test for solidarity and still it is. Solidarity on all levels - international, national, and local - is needed to tackle this public health crisis. Paolo Giordano correctly states that "the lack of solidarity is first of all a lack of imagination." Until someone is personally affected often cannot feel the need to change behavior. It is especially true in case of an invisible disease.

There have been many incidents to demonstrate that policymakers should focus more on the global and public dimensions of health. For instance, on February 26 an urgent request was sent from Rome to the European Commission in Brussels. The message included the specifications of Italy's needs, and was uploaded into the EU's Common Emergency Communication and Information System (CECIS).

As a result of implementing neoliberal economic measures, the public health sector has shrunk significantly, even in Europe. With the current pandemic the relevance of public health has to be reconsidered. The social

8 Dickenson, D., 2016, Me Medicine vs. We Medicine: Reclaiming Biotechnology for the Common Good, New York, Columbia University Press. 
aspects of health have become evident. For instance, if my neighbor does not exercise precaution and does not respect the public health measures, it will influence me too, no matter how good health insurance I bought. If we cannot imagine the consequences of everyone acting the same way as we do, then we are not able to react properly to the safety measures.

\subsubsection{What is the Role of Human Rights Analysis in the Time of Covid-19?}

Public health measures during the pandemic include many compulsory norms applicable not only for the sick but even for the healthy. One specificity of the current state of the Covid-19 pandemic is that there is a great deal of uncertainty about the timeline, and there are many inconsistencies between the first and second wave of the pandemic. In addition, many autocratic or populist governments used the opportunity of the extraordinary times to concentrate more power and to bring through such changes that otherwise would not have been possible. The fear and panic due to the Covid-19 pandemic provoked two fundamentally different social behaviors; the compliance and the need for a strong government, and protest and denial on the other side. In this situation the conception and the role of human rights should be reconsidered.

According to some authors we need to consider the re-balancing and the reinforcement of social rights including the right to health. ${ }^{9}$ When assessing the changes there is often a misconception that liberal democracies failed because of 'too much' human rights - it seems there were not enough.

While globalization is often characterized as interconnectedness on a global scale in which a transnational network of circulating goods, people, and ideas develop, we have come to realize during the last couple months of the pandemic that globalization does not involve global solidarity. As the air traffic has significantly decreased, countries implemented often harsh lockdown measures, even if pandemic is essentially a global phenomenon it has suddenly been seen as a national matter. The virus was often portrayed as a foreign intruder that comes from another country and global activity, including travel was condemned. Measures that were implemented on behalf of public health were often too broad and non-consistent. Some governments even used the time of pandemic for adopting laws that did not serve any public health interests but simply further re-

9 Cusato, E. et al., Some Conceptual Framings, in: Ferstman, C., Fagan, A. (eds.), 2020, Covid-19, Law, and Human Rights: Essex Dialogues, July 1, Colchester, University of Essex, pp. 3-4. 
stricted minority rights, academic or media freedom. All these trends urge the reinforcement of human rights which by their nature are also global.

While connectedness will persist via emails and internet it seems then in the lack of actual encounters compassion also decreases significantly.

\section{Covid-19 Pandemic and the Right to Health}

According to Judith Bueno, ${ }^{10}$ the rise of multilateralism in global health gave birth to global governance after the Second World War. After the Second World War the WHO Constitution already included the human right to the enjoyment of the highest attainable standard of health in 1946. Since then numerous international documents ${ }^{11}$ reinforced the right to health, but this right soon was regarded as problematic, or at least not enforceable. Furthermore, during the last couple of decades, it was believed that right to health is an old-fashioned socialist norm that has no place in the contemporary human rights catalogue. Nevertheless, the Inter-American Court of Human Rights has recognized the relevance of the right to health: in its interpretation the right to health is not an isolated social welfare right but it is essential in assuring the right to life, as well. Of course, implementation of the right to health depends on the availability of financial resources but this pandemic also proved that health care deserves more governmental and public sources. Health is instrumental in exercising almost all kinds of civil political rights and including also other social welfare rights and right to life.

The WHO addressed the component of the right to health in terms of the quality of health care. According to this, health care should be safe (avoiding injuries to people for whom the care is intended), it should be effective (providing evidence-based healthcare services to those who need them). Furthermore, health care should be people-centered, which means that the services respond to individual preferences, needs and values. Timely provision of health care services requires the reduction of waiting times and sometimes harmful delays. The principle of equitable care requires that health care does not vary in quality on account of gender,

10 Bueno, J., Moving Towards Global Solidarity for Global Health through Multilateral Governance in the Covid-19 Response, in: Ferstman, C., Fagan, A. (eds.), 2020, Covid-19, Law, and Human Rights: Essex Dialogues, July 1, Colchester, University of Essex, p. 31.

11 Article 12 of the International Covenant on Economic, Social and Cultural Rights, adopted and opened for signature, ratification and accession by General Assembly resolution 2200A (XXI) of 16 December 1966 entry into force 3 January 1976 Article 11 - The right to protection of health in the European Social Charter. 
ethnicity, geographic location, and socio-economic status. Integrated care involves the need that health care services are available the full range of health services throughout the life course. And finally, efficient care maximizes the benefit of available resources.

In Article 10 of the Salvador Protocol, ${ }^{12}$ the right to health is elaborated in a way that even immunization is mentioned as a specific element of this right.

The Protocol ensures that primary health care is available to all individuals and families in the community. Furthermore, it extends the benefits of health services to all individuals subject to the State's jurisdiction, including the "universal immunization against the principal infectious diseases" and the "prevention and treatment of endemic, occupational and other diseases".

Another important element of this protocol is that it highlights the further guarantees for the vulnerable. By stating the state obligation to satisfy "of the health needs of the highest risk groups and of those whose poverty makes them the most vulnerable".

Stephen Holmes and Cass R. Sunstein provides a more pragmatic justification for health care rights when they state in their book The Cost of Rights ${ }^{13}$ that although the wealthy "could afford the best doctors that money could buy, could not thereby protect themselves from contagious diseases ravaging the poor. Similarly, health care for workers serves the needs of employers. Regular employment and homeownership reduce the level of social instability and violent crime." In brief, according to the authors, public health programs launched in cities because they served the interest of the wealthy and not the poor.

Health expenditures constitute serious challenges to governments, to health care providers, and to patients. The costs of diseases are increasing ${ }^{14}$, partially because we are able to identify more diseases than before, we have more advanced diagnostic tools, and people live much longer than before. Once my doctor said ironically that by improving the health care of many previously untreatable conditions, actually we created an unprecedented diversity of cases that has not been studied before. While Visegrád countries went through the first wave of the SARS-2 pandemic with minimal losses, the second wave of the pandemic

12 Additional Protocol to the American Convention on Human Rights in the Area of Economic, Social and Cultural Rights (Protocol of San Salvador, 1988).

13 Holmes, S., Sunstein, C. R., 1999, The Cost of Rights: Why Liberty Depends on Taxes, New York, W. W. Norton \& Company, pp. 196-197.

14 Baumol, W. J., 2013, The Cost Disease: Why Computers Get Cheaper and Health Care Doesn't, New Haven, Yale University Press. 
hit them strongly and then the weakness within the health care sector accelerated the losses. ${ }^{15}$

When several countries face the inefficiency of their health care it is easy to recognize that poor health conditions threaten all other rights. On an individual level, it means that if I do not get access to health care or to the information related to healthcare, then I cannot protect my basic right to life and health. In the long run this results in violating other rights, as well - the right to free speech, for example. If I'm bound to bed and I have difficulties in engaging in social life because of my poor health, then I cannot exercise fully my other rights.

If the European Union had more capacity to intervene and help, it would have been better prepared for such a pandemic. Preparedness ${ }^{16}$ is a very important concept in disaster ethics and its significance was not properly acknowledged. Health economy focused mainly on financing the actual cases reported by the health care providers.

The Covid-19 pandemic is a public health crisis that has made respecting the individual's right to health difficult. Responses to the pandemic have also posed significant challenges to a wide range of human rights that are the foundation for the individual's physical and mental health and social wellbeing.

One of the main differences between all similar situations in the current and the last hundred years is that, as can be seen from the third, fortunately rarely-read chapters of the old Health Acts, epidemiological measures focus typically on and target those affected by communicable diseases, i.e. patients. Now, however, all inhabitants of the Earth, whether infected or not, have been subjected to drastic coercive measures. As if we had found ourselves in the tale of Sleeping Beauty overnight, our bustling world suddenly became almost motionless.

The Committee on Economic, Social and Cultural Rights issued a General Comment No. 14. (2000) ${ }^{17}$ which provided the detailed normative content of the right to health. The right to health is not to be understood as a right to be healthy. The right to health contains both freedoms and entitlements. The freedoms include the right to control one's health

15 Löblová, O., 2020, Coronavirus: What Went Wrong in the Czech Republic? The Conversation, November 9, (theconversation.com/coronavirus-what-went-wrong-in-theczech-republic-149505, 10.11.2020).

16 Parmar, A., 2019, Ethics of Emergency Preparedness: Issues in Planning for Patient Care During Disasters, Harvard Medical School Bioethics Journal, Summer, (bioethicsjournal.hms.harvard.edu/summer-2019/ethics-emergency-preparedness, 10.11.2020).

17 Substantive issues Arising in the Implementation of the international Covenant on Economic, Social and Cultural Rights. General Comment No. 14 (2000) E/C.12/2000/4. 
and body, including sexual and reproductive freedom, and the right to be free from interference, such as the right to be free from torture, non-consensual medical treatment and experimentation. By contrast, the entitlements include the right to a system of health protection which provides equality of opportunity for people to enjoy the highest attainable level of health.

From one day to the next, health care was transformed into a reduced care system operating according to military rules. In some countries, including Hungary, seconded soldiers and police officers, so-called hospital commanders ${ }^{18}$, headed the hospitals. There was no antecedent to this radical change, which will change the relationship between healers and health authorities on the one hand, and society and health care on the other.

From the very beginning of the pandemic, doctors and patients had to deal with a strange, hitherto unknown measure, and this completely changed our image of health care. Previously, prevention was one of the key elements of any health awareness campaign: "Everyone should see a doctor in time, have regular screening tests, and if they notice any abnormality, see their doctor immediately." This ingrained message was taken over in one fell swoop by a completely different slogan: "Everyone stay at home and only if there is an urgent need should you contact the healthcare system by phone." Most general practitioners, specialist clinics and hospitals suddenly became inaccessible to large numbers of patients. This radically new message will only be erased by a huge awareness campaign and by making hospitals safe again.

Since March, the most widespread representation of 'the hospital' has been the image of doctors and nurses fighting heroically in intensive care units. We saw health workers with wounded faces under the mask, tired and sleepless, facing the pandemic in a vigorous fight, whom we even applauded in the evenings but no longer dared to go near. The images, which we will never forget, were based primarily on the struggle of Italian intensive care physicians recorded in the international media. Since then, we have known that the pandemic emerges in different ways in each country. There are more victims in multigenerational families and nursing homes than in a younger society living in a one-generation family model. The degree of discipline during the pandemic is obviously stronger where people have already lived in an autocratic society in their lifetime, or where vaccinations are mandatory. At the same time, it is thought-provoking

18 In Hungarian: "kórház parancsnok” 287/2020. (VI. 17.) Korm. Rendelet az egészségügyi készlet állagának megóvása érdekében szükséges intézkedésekről Article 3 (Government Decree on the measures necessary to preserve the condition of the health resources). 
that, following the examples of Bergamo and Wuhan, healthcare soon shifted to the logic of disaster healthcare, whereas the objective figures of the pandemic did not justify that.

Infectious disease often provided the basis for restricting autonomous decisions within health care. But in the current Covid-19 pandemic limitations ${ }^{19}$ of rights include mandatory measures, such as isolation, quarantine and even mandatory vaccination. The control of communicable diseases has involved many different forms of restrictive measures. That limits liberty. In liberal democracies such measures can be justified by only important individual and social interests.

In 1905 in the United States Supreme Court held, in the Jacobson v. Massachusetts case, ${ }^{20}$ that compulsory vaccination itself did not constitute an unacceptable violation of individual autonomy, because of the legitimate government interest in protecting public health. Although anti-vaccination movements persist even at the time when the SARS-CoV-2 virus has demanded already 1,270,000 deaths globally, ${ }^{21}$ people are eagerly waiting for the vaccine. It is stipulated that the effective vaccine will be mandatory at least in certain segments of the society.

The other compulsory measure that interferes with liberty is the quarantine. ${ }^{22}$ This is also seemed to be a long-forgotten measure before the Covid-19 pandemic. The first quarantine law goes back to 1374 when a proclamation was issued in Venice that all ships and passengers had to be stationed on the island of San Lazzaro until the special health council gave them permission to enter the city. On July 27, 1377, Ragusa (today Dubrovnik)'s Major Council passed a law "which stipulates that those who come from plague-infested areas shall not enter [Ragusa] or its district unless they spend a month on the islet of Mrkan or in the town of Cavtat, for the purpose of disinfection." ${ }^{3}$ Since the Spanish flu Europe did not witness such harsh measures but in 2020 many countries were forced to implement lockdowns, curfews, quarantines. Returning from a foreign

19 Selgelid, M. J. et al., (eds.), 2011, Infectious Disease Ethics: Limiting Liberty in Contexts of Contagion, Heidelberg, Springer.

20 Jacobson v. Massachusetts, 197 U.S. 11 (1905).

21 See the daily updated statistics of the Coronavirus Resource Center of the Johns Hopkins University at coronavirus.jhu.edu/map.html.

22 The word has Italian roots. During the Black Death ravaging $14^{\text {th }}$ Century in Europe, ships arriving in Venice from infected ports were required to sit at anchor for 40 days (quaranta giorni) before landing, a practice that eventually became known as quarantine.

23 Blažina Tomic, Z., Blažina, V., 2015, Expelling the Plague: The Health Office and the Implementation of Quarantine in Dubrovnik, 1377-1533, Montreal, McGill-Queen's University Press. 
country irrespective of the health condition has been subjected to mandatory quarantine up to 14 days in many countries.

Curfew had been almost entirely unknown for the European citizens since the Second World War, but in the first and second waves of the pandemic in 2020 this measure was implemented in several countries, including France ${ }^{24}$, Italy ${ }^{25}$, Spain ${ }^{26}$, Belgium ${ }^{27}$, and most recently in the United Kingdom $^{28}$. Different forms of curfew were implemented from the overnight curfew and daily restrictions for weeks.

Although different types of coronavirus infections and even the common flu had already many victims, the current SARS-CoV- $2^{29}$ pandemic urged unprecedented responses from the states all around the world. ${ }^{30}$ It is still to be analyzed why particularly this pandemic provoked series of strict measures globally. We have higher expectations to the life span and quality of health that we had in the twentieth century, and the lack of known treatment made this pandemic especially dreadful. Furthermore, there is no particular social class that is more effected by the virus.

\subsection{BENIGN SOCIAL UTILITARIANISM AND ITS LIMITS IN BIOETHICS}

Public health preparedness in disaster medicine was known in the literature in several other contexts. In case of natural disasters, such as earthquake, flood, tsunami fast reaction and efficient health care are crucial. Surprisingly the reciprocity as a moral condition is very rarely mentioned as a condition of legitimacy in public health measures. Solidarity may sound old-fashioned, still mandatory measures would perhaps better worked if people would feel a moral rewards for the sacrifices.

24 Coronavirus: France Extends Overnight Curfew as Cases Surge, BBC News, October 22, 2020 (www.bbc.com/news/world-europe-54646533, 10.11.2020).

25 Horowitz, J., 2020, Italy Announces Restrictions over Entire Country in Attempt to Halt Coronavirus, The New York Times, March 9, (www.nytimes.com/2020/03/09/ world/europe/italy-lockdown-coronavirus.html, 10.11.2020).

26 Tamma, P., 2020, Spain Adopts Curfew, State of Emergency to Curb Coronavirus, Politico, October 25, (www.politico.eu/article/spain-adopts-curfew-state-of-emergency-to-curb-coronavirus/, 10.11.2020).

27 Belgium Becomes Latest European Country to Announce Strict Lockdown amid Soaring Coronavirus Cases, Euronews, October 30, (www.euronews.com/2020/10/30/ belgium-becomes-latest-european-country-to-announce-strict-lockdown-amid-soaring-coronavir, 10.11.2020).

28 Government of the United Kingdom, New National Restrictions from 5 November, October 31, (www.gov.uk/guidance/new-national-restrictions-from-5-november, 10.11.2020).

29 Severe acute respiratory syndrome coronavirus.

30 Lévy, B-H., 2020, The Virus in the Age of Madness, New Haven, Yale University Press. 
The dominance of the utilitarian thinking in the time had a radical impact on the doctor-patient relationship. Such a radical transformation of the doctor-patient relationship has also encouraged bioethical thinking to innovate. On April 14, the Hungarian Medical Chamber (MOK) published a document entitled Ethical Considerations for the Allocation of Medical Resources during the Covid-19 Pandemic. ${ }^{31}$ This is a rather unique and very forward-looking recommendation in the history of the chamber. By publishing ethical considerations, the Chamber's main effort was obviously to try to address, in an open manner, not only the medical but also the philosophical and ethical aspects of the classification of patients used in emergency care (so-called triage) and to show how to allocate scarce resources at the time of the pandemic. It is important and commendable that the MOK respects non-discrimination in its resolution and emphasizes that there should be no disadvantaging of anyone solely on the basis of their age or gender, i.e. the authors of the document have not confined themselves to a single factor in classifying patients.

However, the recommendation was made just after the significant reduction of the number of inpatients was ordered very suddenly at Easter, a month after many outpatient and inpatient facilities became inaccessible to a wide range of patients for an uncertain, long time. Also, to those who have paid health insurance contributions throughout their lives, and who could rightly expect not to have to give up their health care in their old age either, and that this care would accompany them for the rest of their lives.

Each of the six experts invited by the Medical chamber were men with solid expertise. They were esteemed physicians, legal experts, one of them was also the author of the main bioethics textbook. In light of all this, it is perhaps not surprising that a document written with good intentions follows a purely and very rational male logic inspired by utilitarian morality, which seeks to maximize social well-being - sometimes explaining different aspects of possible alternatives in a textbook-like way. In such a complex traumatic situation as the current coronavirus pandemic, it would have been worth listening to the expertise of several women. They are not necessarily the ones who would bring it up, but an approach of care and relationship ethics or an argument based on human rights would have been more likely to have been raised besides the utilitarian approach. I miss the passion for healing, the clear recognition of professional integrity and the right to health care in the document: non-coronavirus patients should not be given up so easily, either!

31 Magyar Orvosi Kamara (Hungarian Medical Chamber) Etikai megfontolások az orvosi erőforrások elosztásához (Ethical Considerations Relaiting to Resource Allocation in Health Care), available in Hungarian (mok.hu/public/media/source/KORONAVÍRUS/MOK_Etikaimegfontolások_Covid19_final.pdf, 10.11.2020). 
Epidemiologists, bioethicists and doctors can help health governance to develop a fair health policy, but a medical body should also make it clear that only as a last resort will it narrow the range of patients to be treated and give up healing the sick. Before doing so, it will use all means to increase the capacity and resilience of healthcare, will request international assistance if necessary, and only as a last case scenario will it move to the military classification triage. Even then, it can only agree to proportionate restrictions on patients' rights, only in a way that is strictly necessary and for the shortest possible period of time. Wherever possible, it shall consult with patient organizations, patients and relatives. In the absence of this, the premature surrender of patients' rights can permanently distort the doctor-patient relationship.

\subsection{THE BLIND FLAIL OF THE PANDEMIC}

Already during spring many professional recommendations envisaged the classical textbook example of allocating scarce resources. The beautifully structured document consistently embraces the essence of a tight disaster recovery service; in the words of Camus, the cruel and blind "flail" of the pandemic. ${ }^{32}$ The recommendation of the MOK is by no means unique in its approach, and the sudden interiorized military discipline has similarly inspired the recommendations of many medical organizations around the world. By this comparison, professionally, the MOK's recommendation is one of the highest standard documents that I have read in the recent months. The shortcomings that concern a more comprehensive, not merely utilitarian approach to the situation and recommendations for the whole healthcare system, apply to most of the professional recommendations made around the world in the context of a pandemic.

The only exception to the approach is the recent emergence of humanist-inspired documents that call for the full preservation of human rights, but do not contain specific professional proposals.

But why should emotions, doubts and individual compassion be included in a document formulated by a professional body, as these can only distort clear-sightedness, the military order of classification? Wouldn't it be calmer, just to accept the rational utilitarian logic that saves more lives? The fact that we cannot remain impassive in certain situations is in itself a kind of moral stand. In the event of a pandemic, a pre-planned scenario can help a lot, but in practice it rarely stands the test, as assessing the severity of a particular condition is not easy for the physician either.

32 Camus, A., 1975, The Plague, New York, Vintage International (originally 1948), pp. 95-97. 
Before the Covid-19 pandemic, the ethical dilemmas of turning the ventilator on and off were discussed by bioethics regarding patients with incurable and terminal conditions. For the past 30 years, ethical standards have been based on the need to respect the intent of the person most affected, the patient. As this was the basic bioethical situation known so far, and because access to ventilators also plays an important role in the treatment of coronavirus patients, it was overstressed not only by Hungarians but also, for example, in the Italian anesthesiologist's recommendation. (Since then, many intensive care physicians have seriously questioned whether it is at all appropriate to put severely coronavirus-infected people on a ventilator in all cases.)

Though from a distance, it may seem that a cool-headed, unbiased classification always produces a fairer result than when we sympathize with those about whom we make decisions. Yet now it is a much greater emotional burden to look into the eyes of a seriously ill, dying or person in need of critical health care, while it is also important for healthcare workers and society as a whole that healers' sensitivity and therapeutic instinct remain after the pandemic. If they have to take a series of measures that run counter to their own moral integrity or raise serious problems of conscience, military treatment will avenge itself in the long run.

It could be important to know how healthcare workers experience the pandemic and what ethical dilemmas they face in the current pandemic situation. For example, what if a healthcare worker only wants to continue working in appropriate protective equipment but does not have the opportunity to do so? Can he or she refuse to provide care in this case? What happens when he or she is mentally and/or physically exhausted, can he or she obtain psychological or other support? How can a doctor and a researcher reveal their doubts if they notice something significant about the treatment of the pandemic? How can healthcare workers' freedom of speech and academic freedom be protected when they come to an important conclusion about the pandemic: when they discover the effectiveness or ineffectiveness of a cure? By what ethical principles do ethics committees judge Covid-19 protocols?

How should they treat seriously ill, dying people who cannot be visited by their relatives? There have also been cases in Italy and the United States where nurses have given the opportunity for patients and their relatives to see each other on a smartphone. Patients may need emotional support to process the psychological traumas caused by isolation, or even when funerals must be postponed. Pregnant mothers cannot have their partners with them during labor; others have had to stop their assisted reproduction process; millions do not go for screening and rehabilitation. 


\section{Covid-19 Pandemic and Some Specific Human Rights}

Healthcare workers can experience unpredictable traumas as a result of sequential and sudden actions, the withdrawal and reorganization of treatments, and a range of issues that deeply affect their own professional integrity. Not only have many healthcare workers and doctors around the world died from the infection, but we know of suicide cases and mental breakdowns that will likely continue after the pandemic is over. Because of all this, I strongly believe that the pandemic must not only be dealt with along the lines of cold rationality, by comparing lives with each other, but also by beginning to alleviate mental injuries.

Before the onset of the second wave of the pandemic, with my colleagues we surveyed societal attitudes related to the coronavirus pandemic among a representative sample of 1,500 in Hungary. ${ }^{33}$ The online survey also included a survey of missed medical treatments. Nearly a third of respondents said they missed some medical treatment during the spring period of the pandemic. A higher proportion of women reported this loss than men.

The current pandemic bears significance for the right to refuse treatment, as well. While most patients have difficulties to receive medical care during the pandemic, because of the limited capacity within the health care, and because of the lack of sufficient covid testing, still in some country's legislators took further steps in legalizing euthanasia. The Netherlands which already allowed the access to active euthanasia even for minors would further go by allowing it also for small children under the age of 12. Austria and Spain are also thinking about taking further steps towards the legalizing euthanasia.

This is not the best time to discuss or to take further steps for allowing euthanasia. Health care capacities have been struggling with providing even normal care. Patients are scared and panicked because of the covid pandemic and therefore additional guarantees are needed when aid-indying is addressed.

In the lack of effective treatment or vaccination, different combinations of medical treatment were applied so far. Although the WHO considered remdesivir not effective, ${ }^{34}$ the anti-coronavirus drug containing the active

33 Sándor, J. et al., 2020, Social Licensing of Privacy-Encroaching Policies to Address Covid-19, CELAB-CEU Research Support Scheme [manuscript].

34 Wu, K. J., Kolata, G., 2020, Remdesivir Fails to Prevent Covid Deaths in Huge Trial, New York Times, October 15, (www.nytimes.com/2020/10/15/health/coronavirus-remdesivir-who.html, 10.11.2020). 
ingredient remdesivir, manufactured by Richter Gedeon Plc. in Hungary, was administered to the first patient on 14 October at the Department of Pulmonology, Semmelweis University. ${ }^{35}$ The patient was a 75 -year-old severely ill woman who arrived at the institution's Covid-19 ward on that day. The Final Report on the use of this medication came out in November $2020 .{ }^{36}$ In this Report the data showed that "remdesivir was superior to placebo in shortening the time to recovery in adults who were hospitalized with Covid-19 and had evidence of lower respiratory tract infection."

The question comes whether the compassionate treatment can be applied in case of very serious Covid-19 condition. Since the development of effective vaccination is desired even the speeding up of the testing has been proposed. Based on this proposal healthy volunteers would be infected by SARS- 2 coronavirus ${ }^{37}$ so that vaccines can be tested faster. Since during the first wave of the Covid-19, the SARS-2 infection a challenge study could take advantage of the lower rate of death in 18-29-year old. In that age group in China, the death rate was $0.03 \%$, not negligible but relatively uncommon.

Russia announced the development of a vaccine against the SARS-2 coronavirus. The vaccine is named Sputnik V ${ }^{38}$. Russia, which has seen almost 1 million cases of Covid-19, said that it would be able to provide 500 million doses of Sputnik V per year.

Desperate and hasty search for therapy raises skepticism among scientists and increases noncompliance by people, which can be detrimental in the time of a pandemic.

Another important ethical issue is how to protect vulnerable groups. The discriminatory use of restrictive measures during pandemic could have been observed already in the $19^{\text {th }}$ century when Chinese immigrants in San Francisco suffered discriminatory treatment during the bubonic plague late $19^{\text {th }}$ century. This issue appeared even in the litigation, in the Wong Wai v. Williamson ${ }^{39}$, and in the Jew Ho v. Williamson cases $^{40}$.

35 Hazaengedték az első remdesivirrel kezelt koronavírusos beteget a Semmelweis klinikájáról, 24.hu, October 26, 2020 (24.hu/kozelet/2020/10/26/koronavirus-remdesivir-semmelweis, 10.11.2020).

36 Beigel, J. H. et al., 2020, Remdesivir for the Treatment of Covid-19 - Final Report, New England Journal of Medicine, Vol. 383, (November 5,), pp. 1813-1826.

37 Plotkin, S. A., Caplan, A., 2020, Extraordinary Diseases Require Extraordinary Solutions, Vaccine, Vol. 38, No. 24 (May 19), 3987-3988, published online on April 20, (doi.org/10.1016/j.vaccine.2020.04.039, 10.11.2020).

38 Burki, T. K., 2020, The Russian Vaccine for COVID-19, The Lancet, Vol. 8, No. 11 (November 2020), pp. e85-e86, published online on September 4, (www.thelancet. com/journals/lanres/article/PIIS2213-2600(20)30402-1/fulltext, 10.11.2020).

39 Wong Wai v. Williamson, 103 F. 1 (C.C.N.D. Cal. 1900).

40 Jew Ho v. Williamson, 103 F. 10, 1900 U.S. App. LEXIS 3847. 
Due to the number of deaths caused by bubonic plague, the City of San Francisco passed an Ordinance that put certain districts under quarantine. According to Jew Ho, the Ordinance was only enforced against persons of Chinese race and nationality only, and not against persons of other races. He further alleged that there has never been a case of bubonic plague within their locality, as such, the action of the defendants in confining and imprisoning him and other Chinese residents was a "purely arbitrary, unreasonable, unwarranted, wrongful, and oppressive interference with their personal liberty" ${ }^{41}$ The Court held that under the circumstances, the general quarantine of the whole district couldn't be continued, by reason of the fact that it was unreasonable, unjust, and oppressive, and therefore contrary to the laws limiting the police powers of the state and municipality in such matters.

When a health crisis unfolds, sensitivity and empathy towards minorities decrease and this may even lead to blaming them for causing the crisis itself. We have seen numerous episodes in history when biopolitical (racist or ageist) biases provided easy responses to emergency situations ${ }^{42}$ and thus minorities, refugees, or the elderly were left behind.

Finally, under normal circumstances medical data and information are protected by the right to privacy and data protection. ${ }^{43}$ Therefore, the disclosure of the health information is in the hands of the patients concerned. But pandemic makes many data essential for planning, assessing and exercising public health control. Health policy during a pandemic requires the monitoring and analysis of the cases, therefore essentially it works with a lot of health data. In addition, contact tracing and the implementation of the rules of the quarantine also constitute a lawful limitation of the right to privacy. New technologies, including various smartphone applications, make it possible that someone's moves, and contacts could be monitored without physical restriction. As people have different attitude to data protection and privacy, they may have a very different attitude to the use of these technologically advanced methods. While someone may think it is less burdensome because they do not need a physical contact with authorities, for the others the lack of full control of their data, the possibility of hacking data may make these forms of tracking and tracing more troublesome. Since infection and the possibility of contamination themselves require the disclosure of health care and personal data. During the covid pandemic countries applied very different kinds of technological

41 Ibid.

42 Lemke, T., 2011, Biopolitics: An Advanced Introduction, New York, New York University Press.

43 Cate, F. H., 1997, Privacy in the Information Age, Washington, Brookings Institution Press. 
methods in assisting the implementation of health care measures, including tracking and tracing infections. ${ }^{44}$

Privacy issues have also occurred when the Hungarian Operational team decided that in case of reporting Covid-19 related mortality they would mention the underlying diseases, as well. At the beginning there were just a small sample, like 16-20 people on the list, therefore people who died in relation to Covid-19 could have been easily identified ${ }^{45}$ For instance, in one occasion a deceased who worked in diplomatic service was mentioned in the media and since he was the youngest at the time of his death everyone could easily find out that the deceased mentioned on the list suffered from alcoholism. In another case of another younger patient of 37-year old woman, the Operation team could not resist to mention that she was obese. Some elements of dignity extend beyond the death of the individual and we have never got used to the open communication of the underlying disease beyond the close family members in case of non-public figures. From epidemiological aspects it would look as if underlying conditions of people would be more relevant than the virus itself.

\section{Is There a More Sensitive Ethical Approach At The Time of The PANDEMic?}

Perhaps it is precisely because of emotional surplus that female leaders have achieved significant success in handling the pandemic by international comparison as well. Finland, Denmark, Iceland, Taiwan ${ }^{46}$, Germany, New Zealand ${ }^{47}$ seem to have shown better results and a more empathetic attitude with female leaders than other countries where men are at the head of the government. In Finland, it was considered important to even consult children. Success, of course, is the result of the combined effect of a country's social structure, geographical location, healthcare system and many other factors.

44 Ada Lovelace Institute, 2020, International Monitor: Public Health Identity Systems, September 22, London, Nuffield Foundation, (www.adalovelaceinstitute.org/ourwork/identities-liberties/international-public-health-identity-systems-monitor/, 10. 11. 2020).

45 Sándor, J., 2020, Health and Legal Policy in Hungary at the time of COVID-19 Pandemic, Medicine and Law, Vol. 39, No. 2, June, pp. 191-205.

46 Yen, W-T., 2020, Taiwan's COVID-19 Management: Developmental State, Digital Governance, and State-Society Synergy, Asian Politics and Policy, Vol. 12, No. 3, July, pp. $455-468$.

47 Kunzmann, K., 2020, How Did New Zealand Control COVID-19? ContagionLive, August 9, (www.contagionlive.com/view/how-did-new-zealand-control-covid19, 10.11. 2020). 
But what does a more sensitive approach, based on feminist care and relationship ethics, mean in practice? Here are just a few examples of how this approach would differ from the traditional, utilitarian approach. Everyone has the same dignity; no one can be just a case to be classified. As a consequence, we cannot give up on anyone until we have done everything possible to raise resources, which can even mean taking on a conflict with the government. A helpless person, even curing him is already hopeless, cannot be left without pain relief and care. If, in an extreme case, a patient's medical treatment still needs to be discontinued due to lack of capacity, other alternatives or symptomatic treatment should be sought. Patients with terminal conditions must also be accompanied, cared for and provided with palliative care. During the triage process, if a negative decision has been made for a patient, and he or she cannot be ventilated or receive infrequent care, his or her care is not and cannot be over.

Even during the pandemic, it is important to ensure that seriously ill patients keep in touch with their relatives: this may only be possible with technical assistance, but fortunately there are now many opportunities for patients to see their relatives at least online, via Messenger, Zoom or other channels. Masks and protective equipment must be tailored to the size of the female and child's body, not only to adult men.

Healthcare workers exposed to increased mental and physical strain should also be expected to receive psychological support and more frequently available rest periods.

Only all these taken together can alleviate the psychological stresses generated during the health care carved in military form, so that a physician-patient relationship that is ideal for healing, yet honest and humane, can develop after the pandemic has subsided. At the same time, with curbing the pandemic, we hope to find ourselves in the healthcare conditions of the $21^{\text {st }}$ century again and to report once again on the effects and moral challenges of the most advanced medical technologies that protect and improve our health.

The losses of lives, the problems within the health care system and problems with compliance with strict measures seem to be even worse during the second wave of the pandemic. The second wave of the Covid-19 pandemic arrived in Europe in September 2020. The number of those infected, hospitalized, and deceased has risen drastically in comparison with the first wave. In some European countries more people die from the complications of Covid-19 in a single week than died during the whole first wave. By mid-November in Hungary nearly 3000 people had died in relation to the Covid-19 pandemic. It seems that the healthcare systems in countries where the first wave was relatively mild, such as in Hungary and the Czech Republic, were unprepared for such an increase. 
Although the international borders have been practically closed since September, the numbers of infected people did not go down; on the contrary, they increased. In September the official communication of the government of Hungary was that the country is an island of safety as opposed to the rest of Europe, thus Hungary was marked green, while all other countries red. This perpetuated the misconception that everything was fine here, and that the virus was just an enemy brought in from abroad. Travelers were indeed quarantined or were only able to get out of quarantine earlier than two weeks at the price of an expensive test, but those actually infected, and their contacts were not automatically quarantined, thus travelers were effectively discriminated against.

Since October 1 public schools have been required to measure body temperature and the limit above which a child could not go to school was set at $37.8^{\circ} \mathrm{C}$. On November 11 the government again implemented a light lockdown in Hungary, with an overnight curfew between 8:00 p.m. and 5:00 a.m.; it ordered the closing of restaurants, cinemas, theatres, fitness centers, cafes; while high schools and universities have to return to online teaching. The Parliament approved the declaration of 'situation of danger' on November 10, 2020.

During the second wave of the pandemic, European states have tried to pursue a different strategy. In addition to sustaining the functioning of the economy, they are trying to curb the pandemic through regional and targeted measures. But after some months it seems that many of them returned to some forms of lockdown.

\section{Alternative Approaches}

The serious restrictions on personal liberty provoked also protests in many places. Lockdowns put the focus on home conditions, while the better offs were locked in spacious houses with garden those who were poor and lived in big cities were often locked in their tiny apartments.

No wonder that movement against restrictions have developed after some months and some other were seeking an alternative model to deal with the health care crisis.

The Great Barrington Declaration ${ }^{48}$ was signed in October 2020. Signatories, such as infectious disease epidemiologists and public health scientists, expressed their grave concerns about the damaging physical and mental health impacts of the prevailing Covid-19 policies, and recommend an approach that they call "Focused Protection:"

48 The Declaration was signed on October 4, 2020 in Great Barrington, United States. 
"Current lockdown policies are producing devastating effects on short and long-term public health. The results (to name a few) include lower childhood vaccination rates, worsening cardiovascular disease outcomes, fewer cancer screenings and deteriorating mental health - leading to greater excess mortality in years to come, with the working class and younger members of society carrying the heaviest burden. Keeping students out of school is a grave injustice." 49

Furthermore, the document also claimed that keeping restrictive measures in place until a vaccine is available will cause "irreparable damage, with the underprivileged disproportionately harmed." 50

The signatories believed that "all populations will eventually reach herd immunity - i.e. the point at which the rate of new infections is stable - and that this can be assisted by (but is not dependent upon) a vaccine." ${ }^{11}$ Therefore, the Declaration aims to minimize mortality and social harm until we reach herd immunity.

In this model which is called "Focused Protection" those who are not vulnerable could be allowed to resume life as normal. Simple hygiene measures, such as hand washing and staying home when sick should be practiced by everyone to reduce the herd immunity threshold. Schools and universities should be open for in-person teaching. Young low-risk adults should work normally, rather than from home. Restaurants and other businesses should open. Arts, music, sport and other cultural activities should resume. People who are more at risk may participate if they wish, while society as a whole enjoys the protection conferred upon the vulnerable by those who have built up herd immunity." 52

These positions nevertheless remain in minority especially as the second wave of the pandemic seem to be even more aggressive in many places.

At the time of writing this chapter there are many promising medications and vaccines are tested, nevertheless we cannot say still anything certain about them. Needless to say, that there are many ethical and legal questions are involved but that deserves a further study. Informed consent procedures, prioritization of the access to available vaccine all require a deeper ethical and legal analysis. ${ }^{53}$ Also, the "freerides of the pandemic", the people who may have immunity passports and one to enjoy a life full scales while other still suffer from restrictions.

\footnotetext{
49 The Great Barrington Declaration, (https://gbdeclaration.org/).

50 Ibid.

51 Ibid.

52 Ibid.

53 The Nuffield Council, 2020, Ten Questions on the Next Phase of the UK's Covid-19 Response (www.nuffieldbioethics.org/assets/pdfs/Ethical-considerations-in-the-nextphase-of-the-COVID-19-response.pdf, 10. 11. 2020).
} 


\section{Conclusions}

The Covid-19 pandemic had an impact on all the health care systems in the world. Having been threatened by the virus already for eight months and still experiencing a unique global health care challenge it is time to draw some conclusions.

This Covid-19 crisis has been a test for solidarity and still it is. Solidarity on all levels, international, national, and local, is needed to tackle this public health crisis. Paolo Giordano correctly states that "the lack of solidarity is first of all a lack of imagination." If we cannot imagine the consequences of everyone acting the same way as we do, then we are not able to react properly to the safety measures. There are differences between societies: some are more individualistic than the other.

As it has become obvious, Covid-19 can be contracted both by the poor and by the rich. No matter how expensive health services someone is able to pay in the lack of public health she/ he may suffer from infection.

The Covid-19 pandemic also transforms our notion of public health and it shapes our concept of the right to health. Under the neoliberal economic discourse, financial support for public health has shrunk significantly even in Europe. During the current pandemic, however, the social aspects of health have become evident. For instance, if my neighbor does not exercise precaution, does not respect public health measures, or has not received a vaccination, then this will have an influence on me, no matter how good and expensive health insurance I have paid for. During the last couple of decades, it was believed that the right to health is an old-fashioned state socialist norm that has no place in the contemporary human rights catalogue. The relevance of the right to health, has nevertheless been recognized by the Inter-American Court of Human Rights which considers it not just as an isolated social welfare right. Of course, the implementation of the right to health depends on the availability of financial resources, but this pandemic also shows that health care deserves more governmental and public sources. Health is instrumental in exercising almost all kinds of civil political rights and including also other social welfare rights and right to life.

If I do not get access to health care or to information related to healthcare, then I cannot protect my basic right to life and health. In a long run this results in violating other rights, as well, e.g. free speech. If I'm bound to bed and I have difficulty engaging in social life because of my poor health, then I cannot fully exercise my other rights.

If the European Union had more capacity to intervene and help, it would have been better prepared for such a pandemic. Preparedness is 
a very important concept in disaster ethics and its significance was not properly acknowledged.

The Covid-19 pandemic is a public health crisis that has made respecting the individual's right to health difficult. Responses to the pandemic have also posed significant challenges to a wide range of human rights that are the foundation for the individual's physical and mental health and social wellbeing.

\section{BIBLIOGRAPHY}

1. Ada Lovelace Institute, 2020, International Monitor: Public Health Identity Systems, September 22, London, Nuffield Foundation, (www.adalovelaceinstitute.org/our-work/identities-liberties/international-public-health-identity-systems-monitor/, November 10, 2020).

2. Ballesteros Sanz, M. Á. et al., and Working Groups from SEMICYUC, 2020, Recommendations of the Working Groups from the Spanish Society of Intensive and Critical Care Medicine and Coronary Units (SEMICYUC) for the Management of Adult Critically Ill Patients in the Coronavirus Disease (Covid-19), Medicina Intensiva, Vol. 44, No. 6.

3. Baumol, W. J., 2013, The Cost Disease: Why Computers Get Cheaper and Health Care Doesn't, New Haven, Yale University Press.

4. Beigel, J. H. et al., 2020 Remdesivir for the Treatment of Covid-19 - Final Report, New England Journal of Medicine, Vol. 383.

5. Blažina Tomic, Z., Blažina, V., 2015, Expelling the Plague: The Health Office and the Implementation of Quarantine in Dubrovnik, 1377-1533, Montreal, McGillQueen's University Press.

6. Boffey, Daniel et al., 2020, Revealed: Italy's Call for Urgent Help Was Ignored When Coronavirus Swept Through Europe. The Guardian, July 15, (www.theguardian.com/world/2020/jul/15/revealed-the-inside-story-of-europes-divided-coronavirus-response, 10. 11. 2020).

7. Bueno, J., Moving Towards Global Solidarity for Global Health through Multilateral Governance in the Covid-19 Response, in: Ferstman, C., Fagan, A. (eds.), 2020, Covid-19, Law, and Human Rights: Essex Dialogues, July 1, Colchester, University of Essex.

8. Burki, T. K., 2020, The Russian Vaccine for COVID-19, The Lancet, Vol. 8, No. 11.

9. Camus, A., 1975(1948), The Plague, New York, Vintage International.

10. Cate, F. H., 1997, Privacy in the Information Age, Washington, Brookings Institution Press.

11. Cusato, E. et al., Some Conceptual Framings, in: Ferstman, C., Fagan, A. (eds.), 2020, Covid-19, Law, and Human Rights: Essex Dialogues, Colchester, University of Essex.

12. Dickenson, D., 2016, Me Medicine vs. We Medicine: Reclaiming Biotechnology for the Common Good, New York, Columbia University Press. 
13. Flynn, T. et al., Global, Regional and Comparative Perspectives, in: Ferstman, C., Fagan, A. (eds.), 2020, Covid-19, Law and Human Rights: Essex Dialogues, Colchester, University of Essex.

14. Giordano, P., 2020, How Contagion Works, London, Weidenfeld \& Nicolson.

15. Government of the United Kingdom, New National Restrictions from 5 November, October 31, 2020, (www.gov.uk/guidance/new-national-restrictions-from-5-november, 10. 11. 2020).

16. Holmes, S. Cass, R. S., 1999, The Cost of Rights: Why Liberty Depends on Taxes, New York, W. W. Norton \& Company.

17. Lemke, T., 2011, Biopolitics: An Advanced Introduction, New York, New York University Press.

18. Lévy, B.-H., 2020, The Virus in the Age of Madness, New Haven, Yale University Press.

19. Mackenzie, D., 2020, Covid-19. The Pandemic that Never Should Have Happened, and How to Stop the Next One, London, The Bridge Street Press.

20. Magyar Orvosi Kamara (Hungarian Medical Chamber) (2020) Etikai megfontolások az orvosi erőforrások elosztásához (Ethical Considerations Relaiting to Resource Allocation in Health Care), (mok.hu/public/media/source/KORONAVÍRUS/MOK_Etikai megfontolások_Covid19_final.pdf, 10. 11. 2020).

21. Morley, J. et al., 2020, Ethical Guidelines for Covid-19 Tracing Apps: Protect Privacy, Equality and Fairness in Digital Contact Tracing with These Key Questions, Nature, Vol. 582, No. 7810, (www.nature.com/articles/d41586-020-01578-0).

22. Nicoli, F., Gasparetto, A., 2020, Italy in a Time of Emergency and Scarce Resources: The Need for Embedding Ethical Reflection in Social and Clinical Settings, Journal of Clinical Ethics, Vol. 31, No. 1.

23. Nuffield Council, 2020, Ten Questions on the Next Phase of the UK's Covid-19 Response, October, London, The Nuffield Council on Bioethics, (www.nuffieldbioethics.org/assets/pdfs/Ethical-considerations-in-the-next-phase-of-the-COVID-19-response.pdf, November 10, 2020).

24. Paget, J. et al., 2019, Global Mortality Associated with Seasonal Influenza Epidemics: New Burden Estimates and Predictors from the GLaMOR Project, Journal of Global Health, Vol. 9, No. 2.

25. Parmar, A., 2019, Ethics of Emergency Preparedness: Issues in Planning for Patient Care During Disasters, Harvard Medical School Bioethics Journal, Summer 2019, (bioethicsjournal.hms.harvard.edu/summer-2019/ethics-emergency-preparedness, 10. 11. 2020).

26. Plotkin, S. A., Caplan, A., 2020, Extraordinary Diseases Require Extraordinary Solutions, Vaccine, Vol. 38, No. 24.

27. Sándor, J., 2020, Bioethics for the Pandemic, Project Syndicate, May 28, (www.project-syndicate.org/commentary/bioethics-principles-for-covid19-response-by-judit-sandor-2020-05).

28. Sándor, J., 2020, Health and Legal Policy in Hungary at the time of COVID-19 Pandemic, Medicine and Law, Vol. 39, No. 2.

29. Selgelid, M. J. et al., (eds.), 2011, Infectious Disease Ethics: Limiting Liberty in Contexts of Contagion, Heidelberg, Springer. 
30. Vergano, M. et al., 2020, Clinical Ethics Recommendations for the Allocation of Intensive Care Treatments, in: Exceptional, Resource-Limited Circumstances, Version No. 1 (Rome: SIAARTI, March 16, 2020), (www.siaarti.it/SiteAssets/News/ COVID19 - documenti SIAARTI/SIAARTI - Covid-19 - Clinical Ethics Reccomendations.pdf.

31. Yen, W-T., 2020, Taiwan's COVID-19 Management: Developmental State, Digital Governance, and State-Society Synergy, Asian Politics and Policy, Vol. 12, No. 3.

\section{Case LaW}

1. Jacobson v. Massachusetts, 197 U.S. 11 (1905).

2. Jew Ho v. Williamson, 103 F. 10, 1900 U.S. App. LEXIS 3847.

3. Wong Wai v. Williamson, 103 F. 1 (C.C.N.D. Cal. 1900).

\section{INTERNET SOURCES}

1. 24.hu, 2020, Hazaengedték az első remdesivirrel kezelt koronavírusos beteget a Semmelweis klinikájáról (The First Patient Treated with Remdesivir Was Released from the Clinic of Semmelweis University), 24.hu, October 26, (24.hu/ kozelet/2020/10/26/koronavirus-remdesivir-semmelweis).

2. BBC, 2020, Coronavirus: France Extends Overnight Curfew as Cases Surge, BBC News, October 22, (www.bbc.com/news/world-europe-54646533, 10. 11. 2020).

3. Boffey, D. et al. 2020, Revealed: Italy's Call for Urgent Help Was Ignored When Coronavirus Swept Through Europe. The Guardian, July 15, (www.theguardian. com/world/2020/jul/15/revealed-the-inside-story-of-europes-divided-coronavirus-response, 10. 11. 2020).

4. Euronews, 2020, Belgium Becomes Latest European Country to Announce Strict Lockdown amid Soaring Coronavirus Cases. Euronews, October 30, (www. euronews.com/2020/10/30/belgium-becomes-latest-european-country-to-announce-strict-lockdown-amid-soaring-coronavir, 10. 11. 2020).

5. Geddie, J., Aravindan, A., 2020, Singapore Plans Wearable Virus-Tracking Device for All, Reuters, June 5, (www.reuters.com/article/us-health-coronavirus-singapore-tech/singapore-plans-wearable-virus-tracing-device-for-all-idUSKBN23C0FO, 10. 11. 2020).

6. Helm, T., Graham-Harrison, E., McKie, R., 2020, How Did Britain Get Its Coronavirus Response So Wrong? The Guardian, April 19, (www.theguardian.com/ world/2020/apr/18/how-did-britain-get-its-response-to-coronavirus-so-wrong, 10. 11. 2020).

7. Horowitz, J., 2020, Italy Announces Restrictions over Entire Country in Attempt to Halt Coronavirus, The New York Times, March 9,(www.nytimes. com/2020/03/09/world/europe/italy-lockdown-coronavirus.html, 10. 11. 2020).

8. Kunzmann, K., 2020, How Did New Zealand Control COVID-19? ContagionLive, August 9, (www.contagionlive.com/view/how-did-new-zealand-control-covid19, 10. 11. 2020). 
9. Löblová, O., 2020, Coronavirus: What Went Wrong in the Czech Republic? The Conversation, November 9, (theconversation.com/coronavirus-what-wentwrong-in-the-czech-republic-149505, 10. 11. 2020).

10. Tamma, P., 2020, Spain Adopts Curfew, State of Emergency to Curb Coronavirus, Politico, October 25, (www.politico.eu/article/spain-adopts-curfew-state-ofemergency-to-curb-coronavirus/, 10. 11. 2020).

11. Wu, K. J., Kolata, G., 2020, Remdesivir Fails to Prevent Covid Deaths in Huge Trial, The New York Times, October 15, (www.nytimes.com/2020/10/15/health/ coronavirus-remdesivir-who.html, 10. 11.2020).

\title{
NOVO BALANSIRANJE LJUDSKIH PRAVA \\ U DOBA PANDEMIJE COVIDA-19
}

\author{
Judit Sándor
}

\section{REZIME}

Godina 2020. sigurno će se spominjati u svim budućim knjigama o istoriji epidemiologije, a o pandemiji Covida-19 raspravljaće se kao o možda najznačajnijem zdravstvenom izazovu počev od španske groznice. Nadam se, ipak, da će se o ovom periodu govoriti i u novim knjigama o zdravstvu i ljudskim pravima. Patnja miliona ljudi širom sveta, smrt i medicinski izazovi doveli su do mnogih pouka iz kojih se već sad može učiti.

Pandemija Covida-19 predstavlja krizu javnog zdravlja koja je otežala poštovanje prava na zdravlje. Štaviše, odgovori na pandemiju izazvali su značajne dileme u zaštiti širokog spektra ljudskih prava koja su temelj za fizičko i mentalno zdravlje i socijalno blagostanje pojedinca. Da bi se izvukle konačne lekcije iz zdravstvene politike i epidemiologije, potrebno je prikupiti dovoljno podataka, što zahteva izvesno vreme.

Moj cilj u ovom članku jeste da ispitam uticaj pandemije Covida-19 na zaštitu ljudskih prava. Ono što u ovom radu tvrdim jeste da globalna pandemija Covida-19 pogađa sva ljudska prava, a naročito pravo na život, slobodu izražavanja, pravo na privatnost, pravo na nediskriminaciju itd. $U$ radu sam se, međutim, fokusirala uglavnom na uticaj pandemije na prava u zdravstvu iz perspektive feminističke etike, a posebno na pravo na zdravlje. Pored toga razmotrila sam i ugroženost prava na odbijanje tretmana i prava na privatnost, prava posebno osetljivih grupa, ali i prava medicinskih radnika. Razradila sam osetljiviji bioetički pristup koji se zasniva na principu brige za razliku od utilitarnih razmatranja. Iako su moje istraživanje i analiza zasnovani prvenstveno na primeru Mađarske tokom dva talasa pandemije, moja procena o stepenu ugroženosti ljudskih prava uzima u obzir, naravno, i globalni uticaj pandemije. 
Jedna od lekcija u borbi protiv pandemije trebalo bi da bude priznavanje prava na zdravlje kao punopravnog ljudskog i ustavnog prava koje zaslužuje mnogo veću pažnju prilikom izrade nacionalnih godišnjih budžeta. Pravo na zdravlje trebalo bi smatrati osnovnim ljudskim pravom bez kojeg se ne mogu ostvariti nikakva druga prava, ne samo u epidemiološkim krizama nego i posle njih. Drugim rečima, ukoliko pojedinac nema pristup zdravstvenoj zaštiti ili informacijama koje se tiču zdravstvene zaštite, ni njeno/njegovo osnovno pravo - pravo na život ne može biti zaštićeno. Osim toga, smatram da su odgovori na pandemiju bazirani na feminističkoj etici mnogo efikasniji i pravičniji nego odgovori koji polaze od utilitarističkog pristupa.

Ključne reči: pandemija Covida-19, ljudska prava, pravo na zdravlje, bioetika, novo balansiranje ljudskih prava.

Article History:

Received: 1 November 2020

Accepted: 25 November 2020 